\title{
Hutton and Hall on theory and experiments: the view after 2 centuries*
}

\author{
Division of Geological and Planetary Sciences, California Institute of Technology, Pasadena, CA 91125, USA.
}

The interplay between observation, theory and experiment focused on the birth of geology as a science, during the period of the Scottish Enlightenment. The fires of Hutton's (1726-1797) Plutonists could not be quenched by the oceans of Werner's (1750-1817) Neptunists. Hall (1761-1832) was convinced that Hutton's "Theory of the Earth" could be proved by experiments, but he deferred to the fears of his older colleague that failed experiments might discredit the Theory (which needed no further proof), and completed the experiments only after Hutton's death. Hutton censured those who "judge of the great operations of the mineral kingdom, from having kindled a fire, and looked into the bottom of a little crucible." Hall believed that "the imitation of the natural process is an object which may be pursued with rational expectation of success." Following many discussions between Hutton and Hall, three topics were pursued in Hall's experiments: 1790, the magmatic origin of granites, younger than schists; 1798, whinstones/dolerites are as magmatic as known lavas; 1805, powdered calcite is transformed to marble and melted by the effects of compression (and water) in modifying the action of heat. The latter involved the first high-pressure, high-temperature apparatus and earned Hall the title "Father of Experimental Petrology". Subsequent development of these three topics is outlined, with particular reference to Scottish contributions, and to debates about primary basalts, granitization, and carbonatites.

\section{Introduction}

Two hundred years ago in 1797, Hutton died, and Lyell was born. At the Bicentennial Conference in Edinburgh celebrating Hutton, I was invited to write about Sir James Hutton and experimental igneous petrology, which leads to the work of Sir James Hall. The subject must be considered in the context of the debate between Werner's Neptunists and Hutton's Plutonists. This debate, with its religious overtones, has become ensconced in textbooks as the classic debate that ushered geology in as a "real science". The theories of Werner (1750-1817) and Hutton (1726-1797) involved global philosophies and implications far transcending the disciplines of mineralogy and mining that preceded them.

Werner's theory, "Neptunism", maintained that all rocks were formed in layers from a primeval ocean, with granite followed by metamorphic rocks, chemical precipitates, and a series of strata as water level fell. Basaltic rock stratified with sediments was thought to be quite different from lavas which had been observed to flow from the relatively few, young, anomalous volcanoes. Werner was one of the great teachers of science, with students flocking to his classes when he began to lecture in Freiberg in 1775, and spreading his gospel after they moved on. He published on a variety of topics, but little on his theory, and he traveled little. But his theorizing was fascinating. The Neptunian Theory faded rapidly after Werner's death in 1817, as his former students tested his theories in the field to seek supporting evidence, and discovered volcanoes, lavas, and intrusive granites.

Hutton's "Theory of the Earth" was presented to the Royal Society of Edinburgh in 1785 and printed in 1788, when Neptunism had ruled for about 10 years. Hutton adduced evidence from observations in the field that granites and basalts had solidified from a molten condition, and appealed not only to the weight of overlying strata and ocean, but also to high temperature at depth. The fiery forces of the earth's interior, he maintained, had fused the deeper rocks. Furthermore, the granites had intruded overlying schists (in modern terms), and were therefore younger, a reverse of the fundamental time sequence required by Werner. Hutton also discovered and explained unconformities, with the implications for repeated processes, mountainous upheavals, erosion, and millions and millions of years, with no end in sight. Lyell (1830-33) later blessed the theory with the name Uniformitarianism, a term replaced by Actualism on the European continent.

Hutton's colleagues were not impressed. Distinguished scientists attacked his new theory. His words "no vestige of a beginning" seemed to deny that the earth had been created, provoking righteous horror (Holmes, 1965, pp.44 and 163). His conclusions were so opposed to Werner's theory that few people paid the theory positive attention. He published an expanded version of his "Theory of the Earth with Proofs and Illustrations" in 1795. As late as 1808, Robert Jamieson, appointed Professor of Natural History in Edinburgh, formed a Wernerian Natural History Society with many publications giving Plutonism a hard time. Hutton's poor writing did not help his case. Playfair (1748-1819), Professor of Natural Philosophy at Edinburgh, decided that the theory merited presentation in more attractive form, and his "Illustrations of the Huttonian Theory" (1802) was effective in this way.

The publications of Hutton and Hall reveal an interesting scientific relationship between them. After an outline of this relationship, I summarize the novel experiments of Hall on granite, basalt and limestone. A brief review of subsequent experiments on these materials up to the present time draws on experiments from my laboratory, and refers selectively to those of scientists based in Edinburgh or Scotland, the home of the remarkable developments in Earth sciences that occurred within a couple of decades near 1800. Newcomb's (1990) account of experiments contributing to geology during $1780-1820$ provides a wealth detail for this period.

* "The Hutton/Lyell Bicentennial Conference" celebrating the death and birth, respectively, of James Hutton and Charles Lyell was held in London and Edinburgh, between 30th July and 9th August, 1997. The Geological Society of London will publish the "Proceedings of the Hutton Bicentennial Conference", editors G. Y. Craig and J. Hull. The editors have kindly given permission for this publication of a modified version of my contribution to the Proceedings. 


\section{Hutton and Hall: Disagreement on theory and experiment}

Hutton's young colleague Hall (1761-1832), at first a disbeliever of Hutton's theory, was slowly converted. He wrote (1805/1812) that: "After three years of almost daily warfare with Dr. Hutton, on the subject of his theory ..." and "I was induced to reject his system entirely, and should probably have continued still to do so, with the great majority of the world, but for my habits of intimacy with the author, the vivacity and perspicuity of whose conversation, formed a striking contrast to the obscurity of his writing." "I thus derived from his conversation, the same advantage which the world has lately done from the publications of Mr. Playfair's Illustrations; and, experienced the same influence which is now exerted by that work, on the minds of our most eminent men of science."

Hall also explained how he developed his experimental ideas, but did not pursue them through deference to the wishes of his older colleague, until after his death in 1795 . He wrote: "conceived that the chemical effects ascribed by him to compression, ought, in the first place, to be investigated ... established in a direct manner by experiment, and I urged him to make the attempt; but he always rejected this proposal, on account of the immensity of the natural agents, whose operations he supposed to lie far beyond the reach of our imitation ... I considered myself bound, in practice, to pay deference to his opinion, in a field which he had so nobly occupied, and abstained, during the remainder of his life, from the prosecution of some experiments with compression, which I had begun in 1790. In 1798 , I resumed the subject with eagerness, being still of opinion, that the chemical law which forms the basis of the Huttonian Theory, ought, in the first place, to be investigated experimentally". The results of this resumption earned Hall the title: "Father of Experimental Petrology".

\section{Experiments: Applicable or not?}

The mature Hutton and the young Hall disagreed on the potential usefulness of experiments, and Hall deferred his experiments out of respect for Hutton. He later (1805, p. 76) wrote that Hutton feared that the experiments would not work: "and he seemed to imagine, that any such attempt must undoubtedly fail, and thus throw discredit on opinions already sufficiently established, as he conceived, on other principles."

Two quotations establish two schools of thought that still influence experimental petrology and its applications:

(1) Hutton (1797) censured those who "judge of the great operations of the mineral kingdom, from having kindled a fire, and looked into the bottom of a little crucible."

(2) Hall (1805) concluded that "the imitation of the natural process is an object which may be pursued with rational expectation of success."

These quotations are reproduced in context below.

In the "Whinstone" paper, Hall provides a detailed account of his enthusiasm to persuade Hutton that experiments would probably prove his Theory. Hall had started his experiments on fusion and cooling rock materials in 1790 , but they were interrupted until Hutton died in 1797, and then resumed winter 1797-98. In 1790, when he presented his interpretation of the fusion and crystallization of granite, Hall (1798, p. 44-45) had: "determined to submit my opinions to the test of experiment. I communicated this intention to all my friends, and in particular to Dr. Hutton; from him, however, I received little encouragement. He was impressed with the idea, that the heat to which the mineral kingdom has been exposed was of such intensity, as to lie far beyond the reach of our imitation, and that the operations of nature were performed on so great a scale, compared to that of our experiments, that no inference could properly be drawn from the one to the other. He has since expressed the same sentiments in one of his late publications (Theory of the Earth, vol. 1, p. 251), where he censures those who 'judge of the great operations of the mineral kingdom, from having kindled a fire, and looked into the bottom of a little crucible.'

"But, notwithstanding my veneration of Dr. Hutton, I could not help differing with him on this occasion: For, granting that these substances, when in fusion, were acted upon by heat of ever so great intensity, it is certain, nevertheless, that many of them must have congealed in moderate temperatures, since many are easily fusible in our furnaces; ... the imitation of the natural process is an object which may be pursued with rational expectation of success; and, could we succeed in a few examples on a small scale, and with easily fusible substances, we should be entitled to extend the theory, by analogy, to such as, by their bulk, or by the refractory nature of their composition, could not be subjected to our experiments. It is thus that the astronomer, by observing the effects of gravitation on a little pendulum, is enabled to estimate the influence of that principle on the heavenly bodies, and thus to extend the range of accurate science to the extreme limits of the solar system."

\section{Observation, theory, experiment and communication}

Science advances through a combination of observation, theory and experiment, but the results become informative only if they are communicated. The preceding remarks have referred to Werner, Hutton, Playfair and Hall. When Hutton's "Theory of the Earth with Proofs and Illustrations" was published in 1795, their ages were: Werner 45, Hutton 69, Playfair 47, and Hall 34. Werner had been a young, inspiring theorist and communicator through 20 years; Hutton's challenging Theory of the Earth, presented at the end of his career, involved theory supported by observation. Playfair communicated Hutton's Theory. Hall did experiments designed to test and prove the Theory.

Werner's Neptunism Theory lasted through about 50 years, 1775-1825. By the time Lyell wrote "The Principles of Geology" (1830-33), the situation was: "The contention of the rival factions of the Vulcanists and Neptunists had been carried to such height that these names had become terms of reproach: and the two parties had been less occupied in searching for truth, than for such arguments as might strengthen their own cause, or serve to annoy their antagonists. A new school at last arose, who professed the strictest neutrality, and the utmost indifference to the systems of Werner and Hutton, and who resolved diligently to devote their labours to observation." "... the reluctance to theorize was carried somewhat to excess ... the time was not yet come for a general system of geology."

The full significance of Hall's experiments appear not to have been recognized by 1830 . According to Lyell: "in order to remove the objections started against this theory, his friend, Sir James Hall, instituted a most curious and instructive set of chemical experiments, illustrating the crystalline arrangement and texture assumed by melted matter cooled under high pressure." Another half century was needed for formulation of Gibbs' Phase Rule, the next significant advance in theory for the experimental approach of melting rocks, and crystallizing melts.

\section{Hutton's theories and Hall's experiments}

I am aware of three papers by Hall, in 1790, 1798, and 1805 (printed 1812). Sir James Hall communicated to the Royal Society of Edinburgh in 1790 "the remainder of his paper, viz. Observations on the Formation of Granite." He gave an abstract of Sir James' (Hutton) observations on the junction between granite and schist, which Hutton was preparing along with a variety of proofs and illustrations of his Theory (the 1795 publication), followed by a discussion of how granitic minerals would melt together, and how fused granite or granite glass would crystallize. His 1978 paper dealt with "Experiments on Whinstone and Lava". His most remarkable paper on "Accounts of a Series of Experiments, shewing the effects of compression in modifying the action of heat" was read to the Royal Soci- 
ety of Edinburgh in 1805 . These papers dealt in turn with granites, basalts, and limestone/marble.

\section{On granite}

In 1790, Hall, an enthusiastic youngster aged 29, summarized the observations of the mature Hutton, aged 64, which challenged and ultimately replaced Werner's theory that granites were primitive, crystalline precipitates from an ocean. "wherever the junction of the granite with the schists was visible, veins of the former, from fifty yards, to the tenths of an inch in width, were to be seen running into the latter, and pervading it in all directions, so as to put it beyond all doubt, that the granite in these veins, and consequently of the great body itself, which he observed forming with the veins one connected and uninterrupted mass, must have flowed in a soft or liquid state into its present position." This observation also indicated that the schist was older than the granite, a reversal of Werner's chronology. Lyell gave a detailed account of Hutton's field explorations and observations around granites.

Hall referred to well-known experiments on melting a crushed mixture of quartz and felt-spar, with felt-spar serving as a flux to the quartz as it runs into "a kind of glass". He described a recent accidental experiment at a "Glass-house" where a mass of glass cooled very slowly and "became white, very hard and refractory", and suggested that if the glass produced by the fusion of granite "had been allowed to cool with sufficient slowness, it might have crystallized, producing a granite familiar to that which was originally melted." He continued with an interpretation of what we now call cotectic melting and precipitation, discussing the formation of some perfect crystals included in a confused mass of feldspar, quartz and schorl. He went on to explain the occurrence of large crystals in a mass of small crystals in terms of slow crystallization in the bowels of the earth, followed by rapid cooling after eruption of the still-liquid solution as a lava. These were novel concepts for the time.

\section{On whinstone and basalt}

Werner maintained that the rock basalt, in its various forms, was quite distinct from the lava erupted from volcanoes. He believed that his theory was based on observations at every point. In 1787 he examined a layer of basalt overlying sand, clay and "wacke", and his observations confirmed to his satisfaction that these layers were all related, and of aqueous origin.

In his 1798 paper "Experiments on Whinstone and Lava", Hall developed the theme outlined for granites in 1790, and applied them also to basalts (p. 43): "Granite, porphyry, and basaltes, are supposed by Dr. Hutton to have flowed in a state of perfect fusion into their present position; but their internal structure, being universally rough and stony, appears to contradict this hypothesis; for the result of the fusion of earth substances, hitherto observed in our experiments, either is glass, or possesses, in some degree, the vitreous character.

This objection, however, loses much of its force, when we attend to the peculiar circumstances under which, according to this theory, the action of heat was exerted. These substances, when in fusion, and long after their congelation, are supposed to have occupied a subterranean position far below what was then the surface of the earth; ... the modification of heat, occasioned by the pressure of the superincumbent mass, ... One necessary consequence ... after their fusion, they must have cooled very slowly; ... appeared to me probable, on that account, that, during their congelation, a crystallization had taken place, ... producing the stony and crystallized structure, ... from the large grained granite to the fine grained and almost homogeneous basalt."

Hall reported observations on rocks, and designed experiments to test Hutton's theory. He compared whinstone (various basaltic rocks, considered by Hall to be "mere varieties of the same class") with lavas from volcanoes, and found close resemblance in external character, mineralogy, and chemical properties. Hall was able to fuse all specimens, and they all behaved the same way, yielding glass with rapid cooling, and stony products with slow cooling. The degree of crystallization depended on rate of cooling and temperature at which rapid cooling was started. He concluded that whinstone, and lavas from volcanoes, were identical in form and origin, and undoubtedly solidified from a molten condition.

Hall also recorded the frequent occurrence of calcareous spar (calcite) in whinstone, but never in lava. He noted that "the compound seems to have entered into fusion, but kept separate, as oil separates from water through which it has been diffused, thus giving rise to the spherical form, which the nodules of calcareous spar generally exhibit with more or less regularity. ... the mutual repulsion of two fluids intermixed, but not disposed to unite." This observation has connections with his subsequent experiments on calcite at high pressures and temperatures, and suggests the occurrence of silicatecarbonate liquid immiscibility, which figures so strongly in current discussions on the origin of carbonatite magmas - magmas which were unimagined until the end of the century.

\section{On limestone and marble}

Hall's greatest achievement was to design apparatus permitting the study of reactions under controlled high pressures and temperatures (with somewhat uncertain values and error bars). His objective was to prove Hutton's theory that many rocks were produced through the action of fire rather than of water: "The essential characteristic principle of his theory is thus comprised in the word Compression; and by one bold hypothesis, founded on this principle, he undertook to meet all the objections to the action of fire" (all quotations in this section are from Hall, 1805).

The knowledge that limestone was decomposed by fire in kilns, and the discovery of carbonic acid by Black (which "explained the chemical nature of the carbonate"), made it seem "absurd to ascribe to that same agent the formation of limestone" or of marble. But according to Hutton's radical hypothesis: "in consequence of the combined action of Heat and Pressure, effects were produced different from those of heat on common occasions; in particular, that the carbonate of lime was reduced to a state of fusion, more or less complete, without any calcination." Hall considered that: "Of all mineral substances, the Carbonate of Lime is unquestionably the most important in a general view." He reasoned that under pressure the volatility of "carbonic acid" would be diminished, and its expansion would be opposed, and the carbonate may be "expected to remain unchanged in a heat, by which, in the open air, it would have been calcined." Then, the carbonate "may be as fusible as the muriate."

Hall completed more than 500 experiments using sealed gun barrels in various experimental designs, with results that demonstrated the decomposition, recrystallization, and melting of crushed calcite. Starting materials included chalk, limestone, spar, marble, and the "shells of fish". The calcite was enclosed in small vessels tubes of glass, porcelain, iron, and tubes or cups of thin plates of platina. The sample was placed at one end of a gun barrel, which was packed with refractory material, and the other end was sealed. Gun barrels were placed vertically or horizontally into a furnace. He designed the first cold-seal pressure vessel, with the sample end of the barrel in the furnace and the cold end of the barrel outside the furnace being closed by a plug and folder to facilitate shutting and opening the barrel. Water was added to some experiments, to increase the pressure, and as we know now this facilitates fusion of calcite (Wyllie and Tuttle, 1960).

The experiments confirmed that powdered calcite can be converted into hard, crystalline marble at high temperatures, as long as pressure is applied (representing a stack of overlying rocks). The physical evidence for melting was unambiguous. Powdered samples settled down to form a solid, void-free mass with surface in the shape of a meniscus. In experiments with periwinkle shells standing upright, the remnants of a shell, with rounded edges, rose from a cup of former liquid, with meniscus, or disappeared altogether into the melted mass with concave surface. 


\section{Experimental petrology of basalt: Developments after Hall}

The views of Hutton and Hall prevailed, and through the 19th century it was generally recognized that the various occurrences of basalt and whinstone, dolerite, or diabase were magmatic. Several petrologists developed the idea of two primary magmas, one basaltic and one granitic, and others developed the idea that granitic magmas were formed from primary basalts through liquation, or crystallization differentiation perhaps facilitated by assimilation.

\section{Phase equilibria in model synthetic systems}

From 1907 at the Geophysical Laboratory in Washington, D.C., the development of furnaces and techniques for the study of liquidus relationships in simple silicate systems defined the possible paths of crystallization in silicate systems and basaltic magmas. Bowen's influential (1928) book marshalled 20 years of experimental data, supported by petrographic observations of rocks, and phase theory (following Gibbs' thermodynamics). Bowen formulated the theory that crystallization-differentiation of a primary basaltic magma was a process capable of generating the diversity of igneous rocks, including granites (from magmas of the Residua System). From the study of binary and ternary model systems came the concept of the Reaction Series, with continuous and discontinuous reaction between minerals and liquid as crystallization proceeded, which is still a central tenet in igneous petrogenesis.

Bowen (1928) proposed that basalt was produced by partial melting of peridotite constituting the mantle, and not from some deep layer of basalt, which was a commonly maintained view through the 1940's (peridotite as a magma source received little further attention until the 1950s). He maintained that basalts never contained more than $12-15 \%$ olivine in solution, and that olivine-rich basalts and picrites represented basalt liquid plus settled olivine crystals. This position was challenged by the detailed petrographic observations of Drever and Johnston (University of St. Andrews) on "Crystal Growth of Forsterite in Magmas and Melts", published in 1957 in the Transactions of the Royal Society of Edinburgh, and republished in 1996 as the first in the "Reprint Series" of forefront Edinburgh papers. They concluded from their interpretation of olivine shapes in their closing sentence that: "What is now beyond reasonable doubt is that large phenocrysts of olivine can crystallize in situ." Hall's assignment of large crystals and small crystals in a rock to two different physical environments is not necessarily applicable to olivine.

Drever supervised my Ph.D. thesis, which (not unnaturally) supported these conclusions (Wyllie and Drever, 1963), and he arranged for me to go to Penn State in 1956 to work with Tuttle and seek experimental verification. I failed, having access to high-pressure equipment that could only reach granitic (and carbonatite) temperatures. The need for experimental investigation of olivine-rich magmas was reinforced 10 years later, when Viljoen and Viljoen (1969) first described the komatiites, characterized by $20-30 \%$ $\mathrm{MgO}$, as a new class of volcanic rocks. Nearly 20 years after the 1957 paper, Drever sent another St. Andrews' student, Donaldson, to Houston in connection with the Lunar Research Program. Donaldson (1976) succeeded in a "detailed experimental investigation of the shapes of olivine crystals grown from mafic and ultramafic melts, showing that they are systematically influenced by the degree of supersaturation during growth, by the rate of cooling of the melt, and by the olivine content of the melt. Essentially all of the shapes illustrated by them in 1957 were reproduced. It then became possible to estimate magma cooling rate and degree of supercooling during olivine growth in individual rocks" (Donaldson, 1996).

The Geophysical Laboratory approach, studying progressively more complex model systems, continued to reveal additional details of magmatic paths. When the piston-cylinder apparatus came into wide-spread use during the 1960 s, the systems were reexamined at higher pressures (corresponding to depths down to about $100 \mathrm{~km}$ ), with the discovery of significant changes in paths of crystallization, and in the nature of reaction relationships. At the same time, attention had shifted to mantle peridotites as the source of basalt magmas, so partial melting processes for model peridotites were also elucidated by these experiments.

\section{Phase relationships of individual rocks: "Dirty systems"}

The Geophysical Laboratory introduced the systematic study of what became known as "dirty systems" with publication by Yoder and Tilley (1962) of an extraordinarily detailed paper: "Origin of Basalt Magmas: an Experimental Study of Natural and Synthetic Rock Systems". They hoped that the "direct but less rigorous approach to the problem", crystallization of a single bulk composition at various pressures, dry and with $\mathrm{H}_{2} \mathrm{O}$ present, would provide "some insight into the general relations of the various basalts in advance of the field and laboratory studies now under way." Note the emphasis on parallel studies of natural rocks and the relevant model systems. Among the pioneers in high pressure phase equilibria studies of peridotites and basalts were F. R. Boyd, H. S. Yoder, A.E. Ringwood, D.H. Green, T.H. Green, and G.C. Kennedy.

The experimental study of natural rocks expanded with the research rush associated with the Lunar Research Program when samples were returned from the moon in 1969. The stimulation of the Plate Tectonics revolution of 1967 opened up additional source rocks and processes to be considered in petrogenetic theory. At this time, the University of Edinburgh began a new phase as a center of experimental petrology under the leadership of M. J. O'Hara, who had spent an apprenticeship period at the Geophysical Laboratory. He wrote an imaginative paper in 1965, not in the Transactions of the Royal Society of Edinburgh, but in the new Scottish Journal of Geology: "Primary magmas and the origin of basalts". The realization that the most abundant magmas on Earth were the basalts oozing from the mid-oceanic ridge system (MORBs), and that these were the best candidates for primary magmas, chemically distinguishable from all other basalts, led to concentration on the mantle-MORB relationship. There have been frustrating experimental problems facing determination of the compositions of melts produced from source peridotite at various depths and temperatures, but with recent developments, the results from model systems and natural rock systems have converged. The mineralogical equations reported for melting reactions, and the compositions of liquids in terms of the components $\mathrm{CaO}-\mathrm{MgO}-\mathrm{Na}_{2} \mathrm{O}-\mathrm{Al}_{2} \mathrm{O}_{3}-\mathrm{SiO}_{2}$, are now in close agreement (e.g. Kinzler and Grove, 1992; Baker and Stolper, 1994; Walter et al., 1995; Gudfinnsson and Presnall, 1996).

The depth of formation of MORBs has been debated through more than 20 years, both sides adducing experimental results to support their conclusions. According to one view, primitive MORBs were generated or segregated from the mantle source at low pressures of 9-11 kbar, and according to the other, picritic primary magmas generated at pressures of about 15-30 kbar experienced extensive olivine fractionation during ascent or in a shallow magma chamber, yielding the primitive MORB compositions. The latter view was championed by O'Hara (1965). The debate collapsed when it was realized that the assumption of a primary magma escaping from equilibrium with the mantle at a specific depth and temperature was invalid. The primary magma concept is now replaced by interpretations which have evolved to dynamic models involving fractional melting during mantle uprise and decompression. Small amounts of melt separate relatively rapidly, and an aggregate of melts collected from a range of depths and temperatures is emplaced into the spreading center where blending occurs. Some of these ideas were initiated in Edinburgh (compare O'Hara and Mathews, 1981). 


\section{Theoretical phase equilibria: MELTS}

Mineral and melt thermochemistry and computer programs have advanced sufficiently that calculated phase equilibria now supplement experiments in increasingly persuasive fashion. Asimow's (1997) "bicentennial" Ph.D. thesis includes thermodynamic models for minerals and melts together with algorithms for seeking equilibrium by potential minimization; he used the MELTS package by Ghiorso and Sack. Among other exercises, he constructed a forward model of MORB genesis. He found that some of the novel aspects of the compositions of melt fractions predicted by MELTS had been anticipated by the experiments of Baker et al., (1995).

Interpretation of the origin of basalts has taken several distinct turns through this century (Basaltic Volcanism Study Project, 1981). The quantity and quality of analytical data on isotopes and trace elements has improved enormously during the past 40 years, placing constraints on theoretical models. The experimental petrology of model systems and of natural rock systems has placed further constraints, but experimental determination of trace element distribution coefficients under varied conditions has lagged. The pendulum appears to have swung away from the time in the early 1960s when natural rock systems were considered "dirty" and somewhat suspect, to a situation where many petrologists regard the simple model systems as too "clean" and inadequate, because they lack important components. The model systems with more than 4 components suffer from the limits of geometrical representation of the compositional relationships, whereas the studies of natural rock compositions with about 10 components do not provide the level of rigorous understanding obtainable from a phase-equilibrium diagram (Presnall, 1986). Both approaches are needed. They complement each other.

\section{Experimental petrology of granite: Developments after Hall}

Hutton's theory that granites were born of fire prevailed over Werner's theory that they were precipitated from ocean water, but Hall's explanation of granite mineral textures in terms of crystallization of a melt did not remain unchallenged. The ability of water at high temperatures to transform other rocks into granites during metamorphism was soon recognized, and the enduring debate between "magmatists" and "granitizers" was under way.

\section{Granitizers and magmatists}

The term "Granitification" was introduced in 1836 by Keilhau. Historical accounts record that "granitization" was embraced by the French School during the 19th century, and by the Fennoscandian School during 19-20th century. Sederholm (from 1907, in 1967) described rocks as "born again" through palingenesis. Anatexis, or refusion, of preexisting rocks to generate a granitic or granodioritic liquid released granites from the parentage of a basaltic magma. A granitic juice, or ichor, of uncertain physical and chemical character was assumed to be capable of granitizing a large volume of rocks; others referred to colonnes filtrantes, pore films, intergranular films, emanations, acid solutions, and migmatite fronts. The transition from metamorphic rocks through migmatites to massive granitic bodies was described by many petrologists, and a wealth of terms was adopted to describe the observations, and their interpretation (Mehnhert, 1967).

During the 1930s and 1940s, the concept of metasomatic fronts was applied to granites and surrounding rocks, and an extreme view developed that large volumes of rocks could be transformed into granites in the solid state, by diffusion of ions on a regional scale. The theories of "dry granitization" were backed up with thermodynamic theory. The debate became bitter. Magmatists and Granitizers or Transformists sometimes had trouble maintaining civility during conversation. Edinburgh was home for influential advocates of granitization.

Geochemical arguments were advanced by Reynolds (University of Edinburgh) to explain advancing granitic fronts. Granitization by the "acid front" introduced ions such as $\mathrm{Si}, \mathrm{Na}$ and $\mathrm{K}$, converting existing rocks to granite, and the excess of non-granitic components such as $\mathrm{Mg}, \mathrm{Fe}$, and $\mathrm{Ca}$ were expelled in a wave of emanations, a "basic front", which became fixed in rocks rich in mafic minerals near the margins of granitic bodies; such marginal rocks are well known. Bowen described this proposal as: "... a basic affront to the geologic fraternity". Reynolds replied: "This is accusing Nature of an intentional break of politeness". Others asked if the elements $\mathrm{Mg}$, $\mathrm{Fe}$ and $\mathrm{Ca}$ are really more mobile than the granitic elements. Perhaps the "basification" was what remained when the mobile granitophile elements emigrated to generate granites elsewhere. Read (1951) wrote: "I suggest for discussion that some basic fronts may be better interpreted as 'Basic Behinds' - a somewhat indelicate term, I admit, but one which expresses the possibility that we may here be dealing with subtraction rocks ... I fly these kites - perhaps a few will still be flying when the experts have finished shooting."

\section{Phase relations in granitic systems with $\mathrm{H}_{2} \mathrm{O}$ under pressure}

Critics of the experimental approach to petrology argued that phase equilibria in simple silicate systems at 1 atmosphere failed to provide a sound basis for interpretation of real rocks not only because there were too few components present to represent the rocks, and because many rocks were formed at high pressures, but also because the effects of the volatile components, the "fugitive" components that disappeared from the magmas during solidification, surely had very important effects which were not taken into account. The ternary Residua System, $\mathrm{NaAlSi}_{3} \mathrm{O}_{8}-\mathrm{KAlSi}_{3} \mathrm{O}_{8}-\mathrm{SiO}_{2}$ (Ab-Or-Qz), actually makes up $90 \%$ or more of the normative components of many granites, but details of the phase relationships at 1 bar had not been worked out because the melts were so viscous, and reactions so sluggish.

There were a few pioneering experiments using $\mathrm{H}_{2} \mathrm{O}$ under pressure in the 1930s and 1940s (e.g. Goranson), but the breakthrough which opened up the field for routine experiments was the design by Tuttle of new experimental equipment, a cold-seal pressure vessel (compare Hall's gun barrels), permitting experimental studies on the melting of granitic minerals and rocks in the presence of $\mathrm{H}_{2} \mathrm{O}$ under pressure. Bowen and Tuttle's (1950) paper on the system $\mathrm{NaAlSi}_{3} \mathrm{O}_{8}-\mathrm{KAlSi}_{3} \mathrm{O}_{8}-\mathrm{H}_{2} \mathrm{O}$ at 1-2 kbar demonstrated the enormous kinetic effect of $\mathrm{H}_{2} \mathrm{O}$ on reactions in silicate melts, the lowering of liquidus temperatures by hundreds of degrees by dissolved $\mathrm{H}_{2} \mathrm{O}$, and the indication that $\mathrm{H}_{2} \mathrm{O}$ under pressure would permit a feldspathic liquid to precipitate both plagioclase and sanidine instead of a single feldspar solid solution.

The granite debate was based largely on observations and their interpretations, without experimental calibration. Field observations, microscopic study of textures, and geochemical analyses of rocks, were interpreted by some as evidence for granitization, whereas others with a different conceptual framework interpreted the same observations in terms of magmatic processes. The experimental studies of Tuttle and Bowen (1958) on the melting of granitic minerals in the system $\mathrm{NaAlSi}_{3} \mathrm{O}_{8}-\mathrm{KAlSi}_{3} \mathrm{O}_{8}-\mathrm{SiO}_{2}$, and natural granites in the presence of $\mathrm{H}_{2} \mathrm{O}$ under pressure (up to $4 \mathrm{kbar}$, equivalent to almost halfway through continental crust), provided the calibrations which led to the convergence of most interpretations to the view that granites are essentially magmatic rocks. The solidus curve marked the beginning of anatexis, and in metamorphic conditions where some transformists argued for ichors or even solid diffusion, it was demonstrated that granitic rocks in the presence of aqueous pore fluid would be partially melted. Associated local granitization was then attributed to aqueous residual melts or solutions. Ten years after publication of these experiments, Turner and Verhoogen (1960, chapters 12 and 15) reviewed history, and stated that: "If the extreme 
hypothesis of granitization by solid diffusion ... is excluded, we find surprising unanimity of opinion in recent writings on the origin and general course of evolution of granitic magmas."

Tuttle and Bowen's (1958) melting curves in the Ab-Or-Qz$\mathrm{H}_{2} \mathrm{O}$ and granite- $\mathrm{H}_{2} \mathrm{O}$ systems were extended to 35 kbar by Huang and Wyllie (1975) and Boettcher and Wyllie (1968). The solidus curve of a natural biotite-granite with excess $\mathrm{H}_{2} \mathrm{O}$ determined by Boettcher and Wyllie (1968) followed remarkably closely that in the model system. Stern and Wyllie $(1973,1981)$ later showed that eutectic-like melting of granitic rocks was limited to crustal pressures, and to $\mathrm{H}_{2} \mathrm{O}$-saturated conditions. The experimental conditions of $\mathrm{H}_{2} \mathrm{O}$-saturation probably obtain only in restricted intervals of magmatic history. Among the many other experimental studies relevant to the origin of granites for which we have no space are those which deal with the vapor-absent melting and crystallization interval of silicate melts with low $\mathrm{H}_{2} \mathrm{O}$ contents, initiated by Robertson and Wyllie (1971). Recent experimental studies relevant to granites have been concerned with the compositions of liquids generated by partial melting of other rocks, such as amphibolite, under vapor-absent conditions (e.g. Wyllie and Wolf, 1993). Detailed reviews on experiments were published in a monograph by Johannes and Holtz (1996).

\section{Experimental petrology of limestone and carbonatites: Developments after Hall}

Hall's experiments demonstrating that the combined effect of heat and pressure (with additional water in some experiments) on calcareous material caused melting and the formation of crystalline masses with the properties of marble was taken as confirmation of Hutton's theory. Lyell, in his "Principles of Geology", proposed the term "metamorphic" for the stratified primary rocks of Werner, and presented examples where "secondary strata have been converted into the metamorphic." In proximity to intruded granite there are examples where "fossiliferous strata have been converted into gneiss, mica-schist, clay-slate, or granular marble"; he referred to limestone becoming coarsely crystalline, and "supposed to have been melted", and to contiguous strata having been reduced to semifusion, and cooling slowly, assuming a crystalline texture. Some time after this (history not known to me), the supposition of partial fusion as a standard process in the formation of metamorphic rocks was dropped, and it was realized that marble was produced by the recrystallization of heated limestone in the solid state. The experimental petrology of limestones and marbles was not pursued further until the 1950s, when Hall's 1805 approach could be resumed with Tuttle's cold-seal pressure vessel making possible the study of carbonate-silicate reactions in the presence of $\mathrm{CO}_{2}$ under pressure.

\section{Alkaline igneous rocks and carbonatites}

Two new sets of observations revived the concept of melted sedimentary limestones and brought them back into the realm of fused rocks, but in a magmatic rather than metamorphic context. The first was Daly's (1910) count that carbonate rocks were present in 107 of 155 alkaline igneous rock associations. The second was the discovery by Högbom (1895) and Brögger (1921) of intrusive rocks called carbonatites, which were associated with alkaline igneous rocks.

Daly launched the limestone syntexis hypothesis, in which basalt (later extended to granitic magmas) dissolved limestone, becoming desilicated with loss of some $\mathrm{CO}_{2}$, forcing the precipitation of nepheline instead of plagioclase, and differentiation to a variety of alkaline magmas. He felt confident that future experimental studies would favor the idea of limestone control on the development of alkaline rock masses. This generated a lively controversy with rather distinct stages. The first, 1910-35, was occupied mainly by arguments about interpretation of field observations. Between 1936-55 the lines of attack and defense became entrenched, and new experimental data in silicate model systems revealed a thermal barrier on the liquidus between subalkaline and feldspathoidal liquids, denying differentiation from one to the other (at 1 atmosphere without volatile components). During the third period, 1956-74, the revived study of carbonatites disrupted the field interpretations for limestone assimilation, and additional experimental data at high pressures in systems containing $\mathrm{H}_{2} \mathrm{O}$ and $\mathrm{CO}_{2}$ made it even more difficult to support the hypothesis. The experimental evidence was reviewed by Wyllie (1974) in Sorensen's (1974) book on "The Alkaline Rocks", and the effects of limestone assimilation are now relegated by most petrologists to some interesting but local phenomena.

Brögger (1921) first used and defined the term "carbonatite", and the rocks have been defined in various ways since then, including: "rocks which, though in general mineral composition similar to limestones and marbles of known sedimentary origin, yet appear to behave as intrusive rocks and are closely associated with alkaline igneous rocks." Brögger and Högbom were convinced that their carbonatites (in Sweden and Norway) were magmatic, probably derived by melting and incorporation into the magma of deep limestones. Bowen argued against the possibility of a carbonatite magma because calcite melts at $1340^{\circ} \mathrm{C}$, far higher than that indicated by field evidence for the supposed carbonatite magmas. Petrologists paid little attention, and carbonatites are not mentioned in most petrology textbooks during 1930-50. In 1945, Shand maintained that carbonatites were mobilized or hydrothermally redistributed limestones, because "imagining a carbonatite magma of unknown origin ... would be a very strange thing."

Intensive prospecting for radioactive elements, niobium, and rare earth elements between 1950 and 1956 resulted in the discovery of many carbonatites, especially in Africa where numerous limestone hills associated with alkaline volcanic regions, ring structures, and central carbonatite plugs were identified as carbonatites. The revival of interest generated three detailed review articles in 1956. The number of localities listed in 1956 increased from 32 to about 320 by 1966, when two books were published (Heinrich, 1966; Tuttle and Gittins, 1966). The 1956 reviews acknowledged the magmatic association, but the high temperature required to melt calcite deterred them from accepting a magmatic origin for the rocks. The 1966 books reported new experimental data confirming the feasibility of carbonatite magmas at suitably low temperatures.

\section{The melting of calcite with $\mathrm{H}_{2} \mathrm{O}$, rediscovered}

Paterson (1958) and Wyllie and Tuttle (1959), independently and ignorant of Hall's 1805 study, reported melting calcite at moderate temperatures in the presence of $\mathrm{H}_{2} \mathrm{O}$ at moderate pressures. Paterson's experiments were aimed at the deformation of marbles. Wyllie and Tuttle were trying to melt calcite in an investigation of carbonatite magmas; in one experiment, a cleavage rhomb of calcite sealed into a gold capsule with water produced a rounded crystal of calcite, rising from a crystalline mass of calcite with a shiny meniscusshaped surface, like a boiled egg in a shallow egg-cup. This was an inadvertant reproduction of Hall's experiment with a periwinkle shell. Wyllie and Tuttle (1960) determined the detailed phase relationships in the system $\mathrm{CaO}-\mathrm{CO}_{2}-\mathrm{H}_{2} \mathrm{O}$. They demonstrated that at pressures above a few bars, molten $\mathrm{CaCO}_{3}$ with dissolved $\mathrm{H}_{2} \mathrm{O}$ would precipitate calcite through a wide range of temperatures down to about $650^{\circ} \mathrm{C}$. Subsequent experiments investigated the phase relationship linking silicate and carbonate-rich melts. The experiments proved that moderate-temperature magmas could exist, capable of precipitating cumulate rocks composed largely of calcite (sövites), but the experimental demonstration of possibilities was not proof that carbonatite magmas did exist.

In dramatic confirmation for the existence of carbonatite magmas in addition to the crystalline carbonatites, Dawson (1962) observed and collected samples of the 1960 and 1961 eruptions of sodium carbonate lavas on to the floor of the crater of Oldoinyo Lengai ("The Mountain of God"), a cone-shaped volcano rising 6,500 feet above the plains in Tanganyika. The erupted magma consists essentially of $(\mathrm{Na}, \mathrm{K})_{2} \mathrm{CO}_{3}$ and $\mathrm{CaCO}_{3}$ in approximately equal 
proportions, with $\sim 4-5 \% \mathrm{Cl}$, and $\mathrm{F}$, and $<2 \% \mathrm{H}_{2} \mathrm{O}$. This indisputable carbonatite lava has composition very different from that of the known carbonatite rocks. Dawson, formerly University of St. Andrews and now University of Edinburgh, has returned repeatedly to the study of these and other carbonatites, and recently presented evidence for liquid immiscibility in the Oldoinyo Lengai lavas (Dawson et al., 1994).

\section{Silicate-carbonate liquid immiscibility, and primary carbonatite magmas}

Hall's (1798) description of calcareous spar in whinstone cited above is expressed in terms of liquid immiscibility between silicate and carbonate components. Koster van Groos and Wyllie (1963) reported their experimental discovery of silicate-carbonate liquid immiscibility in mixtures of plagioclase feldspar and $\mathrm{Na}_{2} \mathrm{CO}_{3}$, with and without $\mathrm{H}_{2} \mathrm{O}$ present. The results indicated that immiscible $(\mathrm{Na}$, $\mathrm{Ca}$ )-carbonate-rich melts could exsolve from plagioclase-nephelinenormative silicate parent magmas, and many subsequent experiments have defined the conditions for silicate-carbonate liquid immiscibility as a function of pressure and bulk composition (e.g. Lee and Wyllie, 1997). This process has obvious applications to the Oldoinyo Lengai lavas, now known as natrocarbonatites.

Theories for the origin of carbonatite magmas included a primary source from the mantle. Dawson and Hawthorne (1973) described an intriguing occurrence of coexisting, differentiated kimberlite and carbonatite within individual sills: "Magmatic sedimentation and carbonatite differentiation in kimberlite sills at Benfontein, South Africa", suggesting the involvement of $\mathrm{CO}_{2}$ in the genesis of kimberlites which are recognized as rocks with deep origins. This is now confirmed by many studies, including isotopes (e.g. in the book edited by Bell, 1989). Eggler (1974) demonstrated that in model mantle-basalt systems, the effect of $\mathrm{CO}_{2}$ under pressure was to deplete the liquid compositions in $\mathrm{SiO}_{2}$, with liquids becoming larnite-normative when they crossed the join forsterite-diopside between 15 and $30 \mathrm{kbar}$, and with $5 \%$ dissolved $\mathrm{CO}_{2}$ depressing the melting temperature by about $75^{\circ} \mathrm{C}$. Wyllie and associates were following subsolidus reactions between model mantle assemblages and carbonates to high pressures and temperatures where melting began, and determining the melting relationships of carbonates, and of simple silicate-carbonate systems. At high pressures within the stability fields of carbonates, the eutectic liquids corresponded to synthetic carbonatites, with 50-90\% dissolved carbonate (about 25-45\% $\mathrm{CO}_{2}$ ). In 1975, Wyllie and Huang combined these experimental approaches, and outlined the comprehensive phase relationships in: "Peridotite, kimberlite, and carbonatite explained in the system $\mathrm{CaO}-\mathrm{MgO}-\mathrm{SiO}_{2}-\mathrm{CO}_{2}$." Many detailed experimental studies have followed, in more complex systems and using natural rocks.

The key, generic conclusions and applications were apparent early in model systems (e.g. Koster van Groos and Wyllie, 1963; Wyllie and Huang, 1975; and subsequent experimental studies). Later experiments with natural rocks provided more details of compositions and temperatures for specific occurrences, with sometimes complex interpretations facilitated by the known model system phase relationships. The primary carbonatite liquid which can be formed in a lherzolite mantle contains only a few per cent $\mathrm{SiO}_{2}$, and is dominated by the composition dolomite (calcic). Continuation of Hall's (1805) pioneering experiments on the effect of pressure and $\mathrm{H}_{2} \mathrm{O}$ in permitting calcite to melt has thus defined the conditions for the generation of carbonatite liquids by the effect of $\mathrm{CO}_{2}$ on upper mantle rocks.

\section{Observation, theory and experiment}

Hutton observed rocks in the field, and developed a "Theory of the Earth" which he felt was sufficiently proved by a second round of observations. Hall carried out experiments designed to prove the theory, confident in the power of experiments despite Hutton's fear that experimental failure would discredit the theory. Hall's experimental confirmation that basalt and granite rocks had solidified from a molten condition has survived later challenges. Hall concluded that he had proved Hutton's theory that marble was formed by fusion of shelly material. His experiments were right, limestone was certainly fusible at high pressures and temperatures with $\mathrm{H}_{2} \mathrm{O}$ present, but the application was wrong. We now know that marbles crystallized in the solid state. The experimental data, however, remain valid, and a parallel approach and follow-up about 150 years later proved that carbonatite magmas could exist. Hall could not have made this application, because carbonatites were not discovered and described until 1895. The fact that experiments showed that carbonate-rich melts could exist did not prove that carbonatite magmas existed - this conclusion required field observations and interpretations.

Petrology is now firmly based on geophysics, and calibrated at depth by experimental petrology. These experiments also contain an element of exploration which is just as stimulating as marching into an uncharted field area. Good experimental data last for ever. Theories, which are based on some combination of observations and imagination, may be supported, denied or destroyed by experimental data. Experiments may deny the feasibility of some proposed theory or process. The interpretation of both field observations and experimental data is strongly influenced by one's conceptual framework, the current theoretical operating systems which process the signals received by the human brain.

\section{Acknowledgements}

I thank Prof. Barry Dawson and the Conference Organizers for the invitation to lecture, and for permission to publish this modified version of the Proceedings paper; the Earth Sciences section of the US National Science Foundation for Grants EAR-9218806 and EAR950577 which have supported my research through many years on granitic rocks, carbonatites, and kimberlites; and Prof. John Gittins for locating H. H. Read's statement about "basic behinds".

\section{References}

Asimow, P.D., 1997. A thermodynamic model of adiabatic melting of the mantle. Ph.D. Thesis, California Institute of Technology, Pasadena.

Baker, M.B., and Stolper, E.M.,1994. Determining the composition of highpressure mantle melts using diamond aggregates. Geochim. Cosmochim. Acta, 58, 2811-2827.

Baker, M.B., Hirschmann, M.M., Ghiorso, M.S., and Stolper, E.M., 1995. Compositions of low-degree partial melts of peridotite: results from experiments and thermodynamic calculations. Nature, 375, 308-311.

Basaltic Volcanism Study Project, 1981. Basaltic Volcanism on the Terrestrial Planets. Pergamon Press Inc., New York, 1286 p.

Bell, K., 1989. Carbonatites. Unwin Hyman, London. 618 p.

Boettcher, A. L., and Wyllie, P. J., 1968. Melting of granite with excess water to 30 kilobars pressure. Jour. Geol., 76, 235-244.

Bowen, N. L., 1928. The evolution of the igneous rocks. Princeton University Press. $334 \mathrm{p}$

Bowen, N.L., and Tuttle, O.F., 1950. The system $\mathrm{NaAlSi}_{3} \mathrm{O}_{8}-\mathrm{KAlSi}_{3} \mathrm{O}_{8}$ $\mathrm{H}_{2} \mathrm{O}$. Jour. Geol., 58, 489-511.

Brögger, 1921. Die Eruptivgesteine des Kristianiagebietes, IV. Das Fengebiet in Telemark, Norwegen. Vidensk. selsk. skrift., I. Mat.-naturv. Klasse, No. 9 (1920)

Daly, R. A., 1910. Origin of alkaline rocks. Bull. of the Geol. Soc. Amer., 21, 87-118.

Dawson, J. B., 1962. The geology of Oldoinyo Lengai. Bull. Volcanology, $24,349-87$.

Dawson, J. B. and Hawthorne, J. B., 1973. Magmatic sedimentation and carbonatite differentiation in kimberlite sills at Benfontein, South Africa Jour. Geol. Soc. London, 129, 61-85.

Dawson, J. B., Pinkerton, H., Pyle, D. M., and Nyamweru, C., 1994. June 1993 eruption of Oldoinyo Lengai, Tanzania: exceptionally viscous and large carbonatite lava flows and evidence for coexisting silicate and carbonate magmas. Geology, 22, 799-82. 
Donaldson, C. H., 1976. An experimental investigation of olivine morphology. Contr. Mineral. Petrol., 57, 187-213.

Donaldson, C. H., 1996. Preface to: H.I. Drever and R. Johnston, Crystal growth of forsteritic olivine in magmas and melts. Reprint series (No. 1), Trans. Roy. Soc. Edinburgh: Earth Sciences, 86, 58-60.

Drever, H.I., and Johnston, R., 1957. Crystal growth of forsteritic olivine in magmas and melts. Trans. Roy. Soc. Edinburgh, 63, 289-315.

Eggler, D. H., 1974. Effect of $\mathrm{CO}_{2}$ on the melting of peridotite. Carnegie Inst. Washington Yearbook 73, 215-224.

Gudfinnson, G.H., and Presnall, D.C., 1996. Melting relations of model lherzolite in the system $\mathrm{CaO}-\mathrm{MgO}-\mathrm{Al}_{2} \mathrm{O}_{3}-\mathrm{SiO}_{2}$ at 2.4-3.4 GPa and the generation of komatiites. Jour. Geophys. Res., 101, 27,701-27,709.

Hall, J., 1790. Observations on the formation of granite. Trans. Roy. Soc. Edinburgh. vol. III, 8-12.

Hall, J., 1798. Experiments on whinstone and lava. Trans. Roy. Soc. Edinburgh, 5, 43-75.

Hall, J., 1812. Account of a series of experiments, shewing the effects of compression in modifying the action of heat. Trans. Roy. Soc. Edinburgh, 6, 71-184. (1805).

Heinrich, E. W., 1966. The geology of carbonatites. Rand Mcnally, Chicago. $555 \mathrm{p}$.

Högbom, A. G., 1895. Uber das nephelinsyenitgebiet auf der Insel Alnö. Geol. Fören. Föhr., 17, 100-160, 214-256.

Holmes, A., 1965. Principles of physical geology. 2nd edition. Ronald Press Company, New York. 1,288 p.

Huang, W. L., and Wyllie, P. J., 1975. Melting reactions in the system $\mathrm{NaAlSi}_{3} \mathrm{O}_{8}-\mathrm{KAlSi}_{3} \mathrm{O}_{8}-\mathrm{SiO}_{2}$ to 35 kilobars, dry and with excess water. Jour. Geol., 83, 737-748.

Hutton, J., 1788. Theory of the Earth; or an investigation of the laws observable in the composition, dissolution, and restoration of land upon the globe. Trans. Roy. Soc. Edinburgh (1785), 1, 209-304.

Hutton, J., 1795. Theory of the Earth, with proofs and illustrations. 2 vols. Edinburgh

Johannes, W., and Holtz, F., 1996. Petrogenesis and experimental petrology of granitic rocks. Springer-Verlag Berlin Heidelberg. 335 p.

Kinzler, R.J., and Grove, T.L., 1992. Primary magmas of mid-ocean ridge basalts 1. Experiments and methods. Jour. Geophys. Res., 97, 6885-6906.

Koster van Groos, A. F. and Wyllie, P. J., 1963. Experimental data bearing on the role of liquid immiscibility in the genesis of carbonatites. Nature, 199, 801-802.

Lee, Woh-jer, and Wyllie, P. J., 1997. Liquid immiscibility in the join $\mathrm{NaAlSiO}_{4}$ $\mathrm{NaAlSi}_{3} \mathrm{O}_{8}-\mathrm{CaCO}_{3}$ at $1 \mathrm{GPa}$ : implications to the formation of crustal carbonatites. Jour. Petrology, 38, 1113-1135.

Lyell, C., 1830-33. The principles of Geology, 3 vols. London.

Mehnhert, K.R., 1968. Migmatites and the origin of granitic rocks. Elsevier, Amsterdam. 393 p.

Newcomb, S., 1990. Contributions from British experimentalists to the discipline of geology: 1780-1820.

O'Hara, M.J., 1965. Primary magmas and the origin of basalt. Scottish Jour. Geol., 1, 19-40.

O'Hara, M.J., \& Mathews, R.E., 1981. Geochemical evolution in an advancing, periodically replenished, periodically tapped, continuously fractionated magma chamber. Jour. Geol. Soc. London., 138, 237-277.

Paterson, M. S., 1958. The melting of calcite in the presence of water and carbon dioxide. Amer. Miner., 43, 603-606.

Playfair, J., 1802. Illustrations of the Huttonian theory of the earth. Cadell and Davies, and William Creech. Edinburgh. (Facsimile reprint with an introduction by G. W. White, 1956. University of Illinois press, Urbana. Reprinted 1964, by Dover Publications, New York).

Presnall, D.C., 1986. An algebraic method for determining equilibrium crystallization and fusion paths in multicomponent systems. Amer. Mineral., $71,1061-1070$

Read, H.H., 1951. Metamorphism and Granitization. Trans. Roy. Soc. S. Africa, 54, 1-17. (also Chapter 7 in: "The Granite Controversy", Murby).

Robertson, J. K., and Wyllie, P. J., 1971. Rock-water systems, with special reference to the water-deficient region. Amer. Jour. Sci., 271, 252-277.

Sederholm, J. J., 1967. Selected Works, granites and migmatites. Wiley \& sons, New York. 608 p.

Shand, S. J. 1945. The present status of Daly's hypothesis of the alkaline rocks. Amer. Jour. Sci., 243-A, 495-507.

Sorensen, H., 1974. The alkaline rocks. John Wiley, London. 622 p.

Stern, C. R., and Wyllie, P. J., 1973. Water-saturated and undersaturated melting relations of granite to 35 kilobars. Earth and Planet. Sci. Letters, 18, 163-167.

Stern, C. R., and Wyllie, P. J., 1981. Phase relationships of I-type granite with $\mathrm{H}_{2} \mathrm{O}$ to $35 \mathrm{~kb}$ : the Dinkey Lakes biotite-granite from the Sierra Nevada batholith. Jour. Geophys. Res., 86, 10412-10422.
Turner, F. J., and Verhoogen, J., 1960. Igneous and metamorphic petrology. McGraw-Hill, New York. 694 pp.

Tuttle, O.F., \& Bowen, N.L., 1958. Origin of Granite in the light of Experimental Studies in the System $\mathrm{NaAlSi}_{3} \mathrm{O}_{8}-\mathrm{KAlSi}_{3} \mathrm{O}_{8}-\mathrm{SiO}_{2}-\mathrm{H}_{2} \mathrm{O}$. Geol. Soc. Amer. Mem. 74, Geol. Soc. Amer. 153 pp.

Tuttle, O. F. and Gittins, J., 1966. Carbonatites, Interscience, New York, 591 p.

Viljoen, M. J., and Viljoen, R. P., 1969. Evidence for the existence of a mobile extrusive peridotitic magma from the Komati formation of the Obverwacht Group. Geol. Soc. S. Africa Spec. Publ., 2, 87-112.

Walter, M. J., Sisson, T.W., and Presnall, D. C., 1995. A mass proportion method for calculating melting reactions and application to melting of model upper mantle lherzolite. Earth and Planet. Sci. Lett., 135, 77-90.

Wyllie, P. J., 1974. Limestone assimilation, in H. Sorensen, editor, Alkaline Rocks. Chapter VI.3, 459-474, John Wiley and Sons, 622 p.

Wyllie, P. J., and Drever, H. I., 1963. The petrology of picritic rocks. A picrite sill on the Island of Soay (Hebrides). Trans. Roy. Soc. Edinburgh, 65 (1961-1962), 155-177.

Wyllie, P. J., and Huang. W. L., 1975. Peridotite, kimberlite, and carbonatite explained in the system $\mathrm{CaO}-\mathrm{MgO}-\mathrm{SiO}_{2}-\mathrm{CO}_{2}$. Geology, 3 , 621-624.

Wyllie, P. J., and Tuttle, O. F., 1959. Melting of calcite in the presence of water, Amer. Miner., 44, 453-459.

Wyllie, P. J., and Tuttle, O. F., 1960. The system $\mathrm{CaO}-\mathrm{CO}_{2}-\mathrm{H}_{2} \mathrm{O}$ and the origin of carbonatites. Jour. Petrology, 1, 1-46.

Wyllie, P. J., and Wolf, M. B., 1993. Amphibolite-dehydration melting: sorting out the solidus. p. 405-416 in (eds), H.M.Pritchard, T. Alabaster, N.B.W. Harris, and C.R. Neary. Magmatic processes and plate tectonics. Geol. Soc. Spec. Paper No. 76, London.

Yoder, H. S., and Tilley, C. E., 1962. Origin of basalt magmas: an experimental study of natural and synthetic rock systems. Jour, Petrology, 3 , $342-532$.

Professor Peter J. Wyllie graduated in geology from the University of St. Andrews (Scotland). With the Royal Air Force (Scotland) he became Heavyweight Boxing Champion. For exploration with the British North Greenland Expedition (1952-54) he received the Polar Medal from H.M. Queen Elizabeth. After emigration to USA his research in experimental petrology dealing with the origin of batholiths, andesites, kimberlites and carbonatites has generated almost 300 publications. He has also written two textbooks, and edited others. He is a Fellow or Foreign Member of 7 National Science Academies, and is currently President of the International Union of Geodesy and Geophysics.

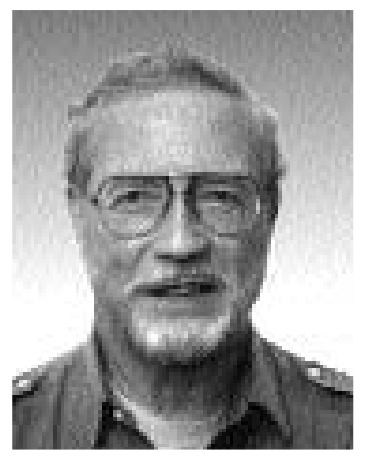

